\title{
PERANCANGAN PHOTOBOOK UNTUK MELESTARIKAN KULINER PECEL SEMANGGI KHAS KOTA SURABAYA
}

\author{
Briantito Adiwena ${ }^{1}$ \\ Angga Hendrawan ${ }^{1}$ \\ Shisi M. Rizky K.A. ${ }^{1}$ \\ Institut Informatika Indonesia, Surabaya ${ }^{l}$ \\ briantito@ikado.ac.id
}

\begin{abstract}
Abstrak
Pecel semanggi adalah makanan khas Surabaya yang terbuat dari daun semanggi yang dikukus dan dinikmati dengan saus yang terbuat dari ketela rambat. Kehadiran penjual semanggi saat ini di Surabaya sudah jarang dijumpai sehingga masyarakat khususnya remaja tidak terlalu mengenal kuliner khas Surabaya ini. Untuk melestarikan keberadaan pecel semanggi yang juga merupakan salah satu ikon Surabaya, peneliti merancang karya photobook yang berisi tentang perjalanan proses pembuatan pecel semanggi dari awal daun semanggi dipetik, diolah dan dijual kepada konsumen.

Perancangan photobook dilakukan dengan observasi dan wawancara kepada pedagang pecel semanggi untuk mengidentifikasi dan memahami seluruh aktivitas yang terjadi selama proses pembuatan pecel semanggi. Dari data tersebut disusun storyboard sebagai panduan dalam menentukan alur pengambilan foto.

Perancangan ini menghasilkan tiga seri photobook dengan menggunakan konsep fotografi aktivitas manusia. Isi dari tiga seri photobook menceritakan proses pemetikan daun semanggi, pengolahan daun semanggi menjadi makanan siap saji, dan proses pemasaran dari pecel semanggi langsung ke konsumen. Penggunaan fotografi aktivitas manusia bertujuan untuk menggambarkan aktivitas manusia didalam sebuah frame dengan berbagai makna yang terkandung di dalamnya.
\end{abstract}

Kata kunci: photobook, fotografi aktivitas manusia, pecel semanggi.

\begin{abstract}
Pecel semanggi is a typical Surabaya food made from steamed clover leaves and served with a sauce made from sweet potato. The presence of pecel semangi sellers in Surabaya is rarely found making many people, especially teenagers, not too familiar with this typical Surabaya culinary. To preserve the existence of the pecel semanggi,
\end{abstract}


which is also one of the icons of Surabaya, the researchers designed a photobook that contains the journey of making pecel semanggi from the beginning when clover leaves are picked, processed and sold to consumers.

The design of the photobook was made by observing and interviewing the Pecel Semangi traders to identify and understand all the activities that occur during the process of making Pecel Semanggi. From the data, a storyboard is prepared as a guide in determining the flow of taking photos.

This design resulted in three series of photobooks using the concept of human activity photography. The contents of the three photobook series tell the process of picking clover leaves, processing clover leaves into ready-to-eat food, and the marketing process from clover pecels directly to consumers. The use of human activity photography aims to describe human activities in frames with various meanings contained in them.

Key words: photobook, human activity photography, pecel semanggi.

\section{PENDAHULUAN}

Indonesia memiliki banyak jenis makanan khas dari masing-masing wilayahnya, hal ini terjadi karena Indonesia memiliki beberapa provinsi. Dimana setiap provinsi mempunyai makanan khas daerahnya masing-masing dan makanan tersebut menjadi bagian dari identitas daerah tersebut. Keanekaragaman suku bangsa dengan budaya, bahasa, agama, adat istiadat yang berbeda menciptakan aneka ragam makanan, dan minuman yang juga menjadi ciri khas suatu daerah. Surabaya sebagai ibukota provinsi Jawa Timur juga memiliki makan yang menjadi salah satu ciri khas, yaitu pecel semanggi.

Surabaya sebagai salah satu pusat perdagangan yang mempertemukan berbagai budaya dari berbagai etnis memberikan pengaruh terhadap jenis kuliner yang ada di Surabaya. Hal ini yang menjadikan Surabaya memiliki potensi sebagai tujuan wisata kuliner dengan banyak pilihan menu yang dapat dinikmati dari kalangan atas hingga menengah. Pecel semanggi sebagai salah satu kuliner asli Surabaya yang masih dijual berkeliling dengan cara digendong panggul perlahan mulai tersingkirkan dengan kuliner lainnya yang dijual dengan cara modern dan dapat dengan mudah dijumpai diberbagai tempat. 


\section{LANDASAN TEORI}

Fotografi berasal dari bahasa Yunani, yaitu "fos" yang artinya cahaya dan "grafo" yang artinya melukis atau menulis. Arti fotografi dalam bahasa inggris (photography) adalah sebuah seni, ilmu pengetahuan dan praktik menciptakan gambar yang tahan lama dengan merekam cahaya atau radiasi elektromagnetik lain, baik secara kimia dengan menggunakan film fotografi atau secara eletronik melalui sebuah sensor gambar. Sedangkan dalam kamus Bahasa Indonesia, arti fotografi adalah seni atau proses penghasilan gambar dan cahaya pada film. (idseducation.com, 2018)

Photo story mampu menyampaikan sebuah pesan yang kuat, membangkitkan semangat, menghadirkan perasaan haru, menghibur, hingga memancing perdebatan. Dalam photo story terbagi dalam tiga bagian yaitu deskriptif yang memuat cerita dokumenter, naratif yaitu sebuah karya fotografi yang berupa narasi yang bertutur dari satu kondisi hingga kondisi berikut namun sangan berbeda dengan kronologi, dan yang terakhir adalah esai yang berupa foto yang berisi rangkaian pendapat dimana muatan opini dari fotografer sangat besar dan biasanya disertai teks panjang.

Dokumenter secara umum, yaitu segala sesuatu representasi non-fiksi di buku atau visual. Sebuah foto dokumenter adalah suatu visualisasi dunia yata yang dilakukan oleh seorang fotografer yang ditunjukan untuk mengkomunikasi sesuatu yang penting, untuk memberi pendapat atau komentar, yang tentunya dimengerti oleh khalayak. Dalam fotografi dokumenter memiliki element utama yaitu foto realitas, sementara estetika dan dan kreativitas berfungsi sebagai pelengkap. Dalam sebuah karya fotografi dokumenter teks atau artikel yang dibawa dalam sebuah karya fotografi tersebut dapat memberikan konteks yang diperlukan dalam pembawaan karya fotografi tersebut. Sehingga audiens mendapatkan pesan yang utuh dalam menikmati karya fotografi tersebut. yang terpenting adalah pengantar yang menyampaikan paparan tentang suatu isu yang dibentuk dalam sebuah karya fotografi dokumenter. 


\section{METODE PENELITIAN}

Dalam penelitian ini untuk mendalami permasalahan yang terjadi maka dilakukan beberapa tahap penelitian yaitu: 1) Wawancara dengan narasumber yang dilakukan dengan para petani semanggi dan penjual kuliner pecel semanggi untuk mendapatkan informasi dan fenomena permasalahan yang akan dibahas.; 2) Melakukan survei lokasi yang akan digunakan dalam pengerjaan karya fotografi.; 3) Mengumpulkan data sekunder melalui internet, buku literatur hingga observasi sehingga memperkuat data penelitian yang digunakan dalam perancangan ini.

\section{HASIL DAN PEMBAHASAN}

Sebelum melakukan perancangan ini diperlukan sebuah konsep yang diperoleh dari penentuan kata kunci. Kata kunci diperoleh dari fenomena, inti masalah serta target audiens. Kata kunci yang digunakan adalah kuliner pecel semanggi khas kota Surabaya yang artinya menggambarkan kekhasan kuliner pecel semanggi dan membawa kuliner khas kota Surabaya sebagai positioning. Dari kata kunci tersebut kemudian dikerucutkan menjadi "Jejak Rasa" yang artinya menmbahas perjalanan kuliner pecel semanggi tersebut dari awal daun semanggi tersebut di petik hingga dijual dan disajikan kepada konsumen. Perancangan layout yang digunakan dalam peracangan ini adalah photobook.

\section{Photobook}

Photobook adalah sebuah media utama yang digunakan sebagai media tentang kuliner Pecel Semanggi yang menjadi kuliner khas Kota Surabaya. Photobook ini akan berisikan foto dan deskripsi untuk memudahkan audience dalam memahami foto yang disajikan. 


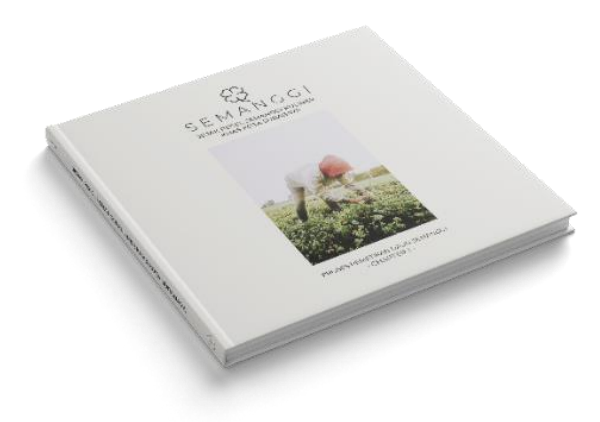

Gambar 1. Photobook

Sumber : Dokumen Pribadi

\section{Sketsa Sampul Buku}

Sampul buku atau cover buku didesain dengan menampilkan foto yang mewakili isi cerita foto yang akan di bawa. Menggunakan komposisi simetri sehingga secara visual semua akan terpusat ditengah, mulai dari judul, foto sampul dan nama fotografer. Hal ini bertujuan supaya buku dapat dengan mudah diidentifikasi oleh audience.
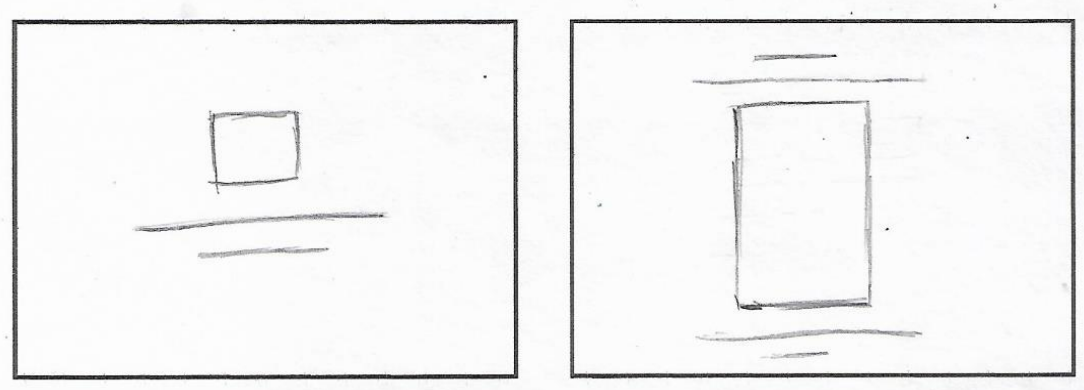

\section{Gambar 2. Sketsa Desain Sampul}

Sumber: Dokumen Pribadi

\section{Sketsa Layout Buku}

Layout yang akan digunakan menggunakan white style ditujukan agar audience dapat menikmati dan memahami isi buku dengan fokus langsung terhadap foto yang menjadi media utama dalam perancangan photobook ini. 
Menggunakan 7 (tujuh) kombinasi komposisi foto dan teks supaya audience dapat menikmati foto dengan beberapa sajian komposisi yang menarik.
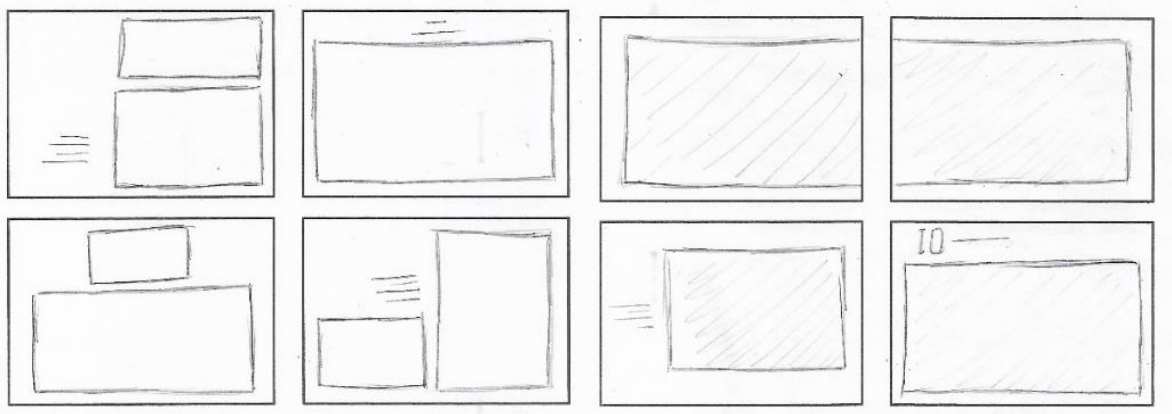

\section{Gambar 3. Sketsa Layout Buku \\ Sumber: Dokumen Pribadi}

\section{Proses Editing Karya Fotografi}

Perancangan dari hasil sketsa visual key atau story board dilanjutkan dengan proses olah digital menggunakan software program Adobe Lightroom. Olah digital dilakukan untuk menyempurnakan komposisi foto dengan metode cropping untuk mendapatkan beberapa komposisi dengan dasar rule of third dimana objek diletakkan kedalam 3/9 hingga 6/9 dari komposisi grid dalam 1 frame, dan mengatur colour gradding untuk membangun suasana dalam foto.

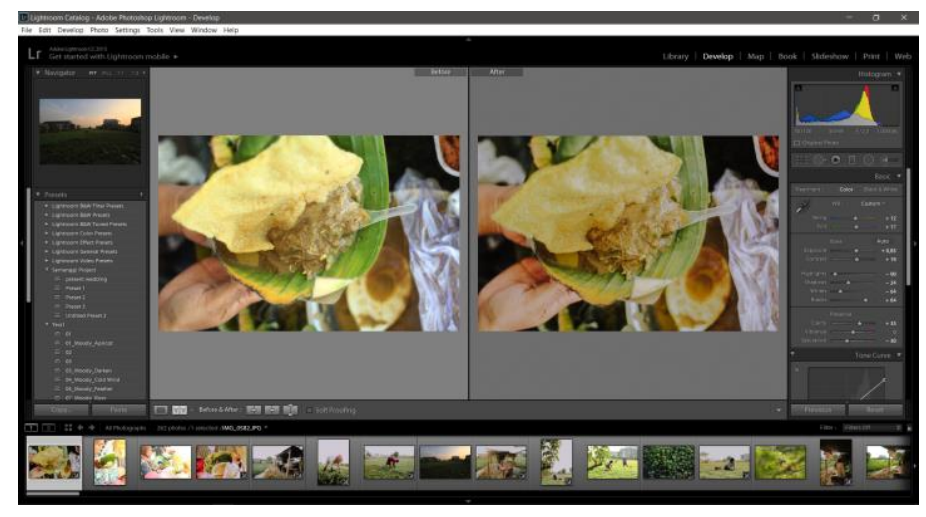

Gambar 4. Proses Olah Digital Foto

Sumber: Dokumen Pribadi 


\section{Proses Digital Desain Sampul}

Setelah melalui proses sketsa dan disempurnakan, desain sampul akan menampilkan salah satu foto yang masuk dalam photobook dengan mengunakan layout white space. Foto yang dipilih adalah foto yang memiliki nilai emosional yang divisualisasikan dengan gestur badan, ekspresi wajah maupun aktivitas yang dilakukan objek foto.

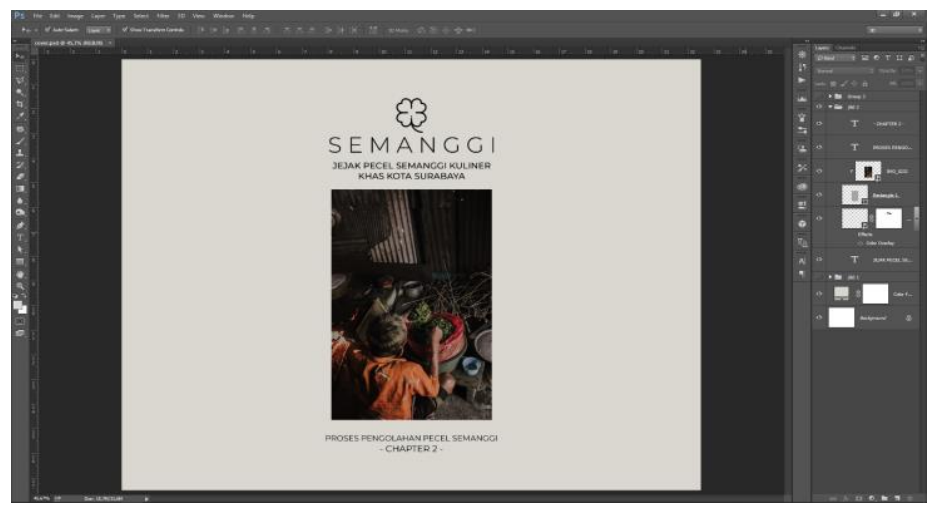

\section{Gambar 5. Proses Olah Digital Layout}

Sumber: Dokumen Pribadi

\section{Proses Digital Layout}

Setelah memalui proses sketsa dan penyempurnaan layout buku, desain layout mengunakan gaya desain white space dan tipografi mengunakan karakter huruf yang simple dan minimalis sehingga dapat mempermudah pembaca untuk memahami dan membaca dengan baik. Layout disusun dengan sesekali menampilkan 1(satu) komposisi layout foto full frame untuk menampilkan momen terbaik dari serangkaian kegiatan pembuatan pecel semanggi, menampilkan layout 2 (dua) foto dalam satu halaman untuk menampilkan momen yang berurutan dan menampilkan layout dengan kombinasi text narasi untuk menampilkan momen beserta detail aktivitas yang dijelaskan melalui deskripsi tertulis. 


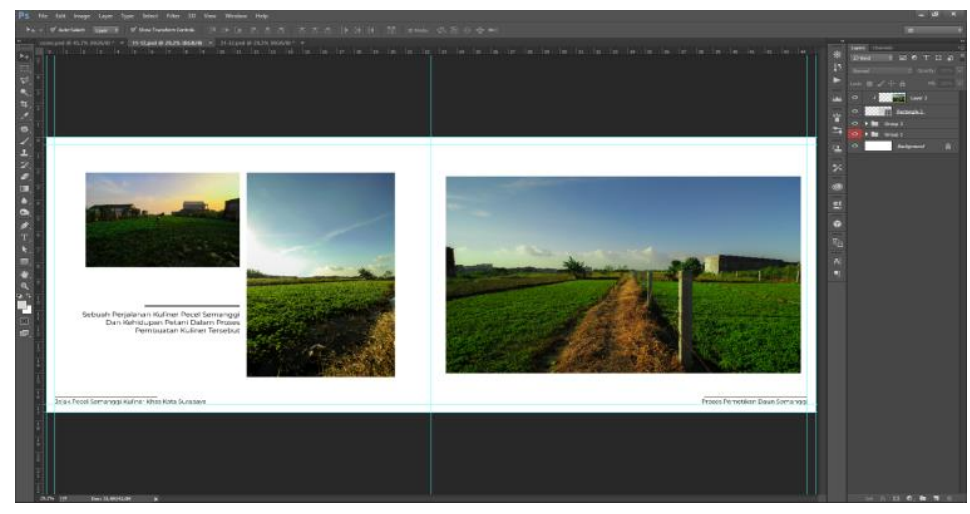

Gambar 6. Proses Olah Digital Layout

Sumber: Dokumen Pribadi

\section{Media Pendukung Kaos}

Setelah melalui proses sketsa desain dan penyempurnaan desain, desain kaos yang dibuat dengan media kain combed dengan sablon plastisol dengan gaya desain minimalis dan simple dengan menampilkan logo type dengan warna dasar hitam. Kaos berfungsi merchandise sekaligus sebagai media promosi yang bisa digunakan audience dalam beraktivitas sehari-hari.

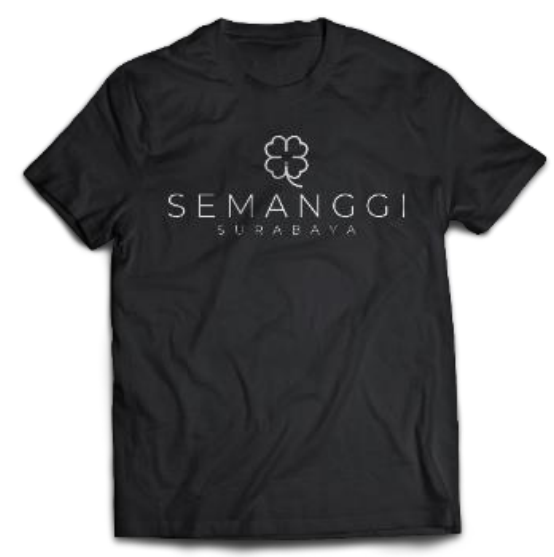

Gambar 7. Desain Media Pendukung Kaos

Sumber: Dokumen Pribadi 


\section{Desain Media Pendukung Stiker}

Setelah melalui proses sketsa desain dan penyempurnaan desain, desain stiker menampilkan logo type dengan finishing cetak digital printing. Stiker ini akan menjadi bagian merchandise yang akan disertakan dalam pembelian photobook.

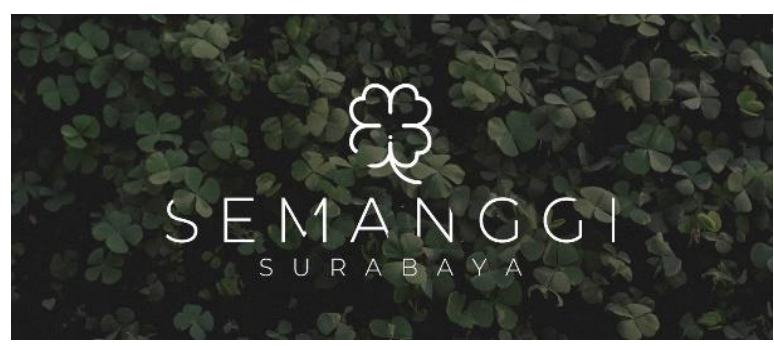

Gambar 8. Desain Media Pendukung Stiker

Sumber: Dokumen Pribadi

\section{Desain Media Pendukung Pembatas Buku}

Setelah melalui proses sketsa desain dan penyempurnaan desain, maka desain pembatas buku mengunakan gaya desain yang minimalis dan menampilkan foto yang menjadi fokus utama desain pembatas buku.

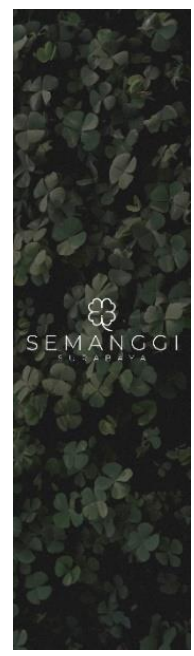

Gambar 9. Desain Media Pendukung Pembatas Buku Sumber: Dokumen Pribadi 


\section{Desain Media Pendukung Kartu Pos}

Setelah melalui prose desain dan penyempurnaan desain, desain kartu pos menampilkan karya fotografi dengan menampilkan font yang simple. Kartu pos digunakan sebagai merchandise yang bersifat collector item.

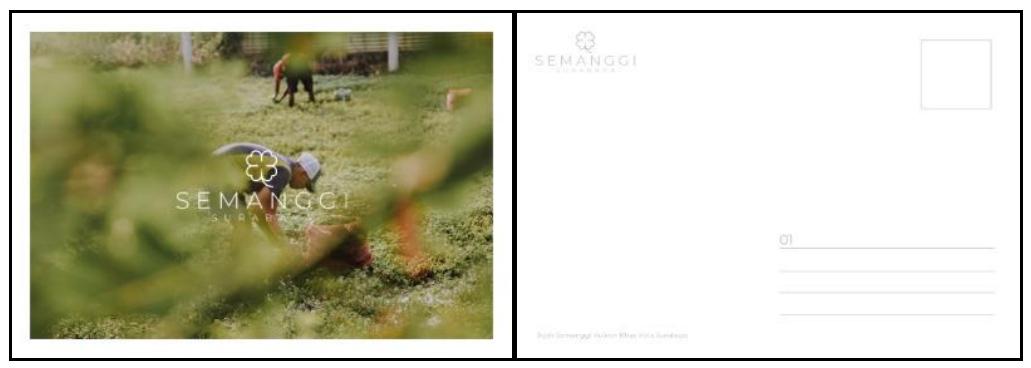

\section{Gambar 10. Desain Kartu Pos}

Sumber: Dokumen Pribadi

\section{SIMPULAN DAN SARAN}

\section{Simpulan}

Dari penelitian yang telah dilakukan, dapat disimpulkan bahwa banyak hal yang belum diketahui oleh sebagian besar masyarakat mengenai bagaimana proses produksi pecel semanggi berlangsung. Mulai dari proses memetik daun semanggi, mengolah daun semanggi, hingga mempersiapkan dagangan pecel semanggi dan menjajakan di sudut-sudut kota Surabaya. Perancangan photobook ini berhasil merangkum sebagian besar aktivitas pedagang semanggi mulai dari memetik, mengolah dan menjual pecel semanggi sehingga audience mendapatkan informasi lebih terkait proses tersebut. Banyak beberapa proses yang masih dilakukan secara tradisional yang seharusnya bisa menjadi nilai tersendiri sehingga audience dapat lebih mengapresiasi kehadiran pecel semanggi sebagai kuliner khas kota Surabaya.

\section{Saran}

Kepada peneliti yang akan mengambil topik serupa, maka disarankan untuk dapat memperhatikan supaya cermat dalam melakukan observasi dan 
wawancara karena dari tahap tersebut peneliti dapat menemukan sudut pandang lain dari sisi objek. Sehingga hal tersebut dapat membantu peneliti dalam menyusun konsep foto yang kreatif bahkan memiliki ciri khas dari beberapa konsep photobook pada umumnya.

\section{DAFTAR PUSTAKA}

Anggraiini Y. (2018) Komposisi dan Manfaat semanggi dari http://yoananggrablog.blogspot.com/2017/10/komposisikimia-dan-manfaat-semanggi.html diakses pada tanggal 18 desember 2018 pada pukul 20:55

GUMILAR ARGI (2017) http://fotografi.upi.edu/home/6-keahliankhusus/2-dokumentasi Diakses pada tanggal 3 April 2019 Pukul 14.22

2018) Desain Komunikasi Visual dari https://pakarkomunikasi.com/komunikasi-visual diakses pada tanggal 12 Januari 2019 pukul 20:15

(2018) Food (2018) Photography dalam photobook dari http://repository.unpas.ac.id/28047/ diakses pada tanggal 11 januari 2019 pukul 08:25

PULO DARMA G. (2010) Desain Komunikasi Visual - Teori https://designideasdkv1.wordpress.com/apa-itu-desainkomunikasi-visual/ Diakses Pada Tanggal 20 Januari 2019 Pukul 16:45

SUGIARTO

A.

Dokumenter https://books.google.co.id/books?id=c4kcBO2awv0C\&pg $=$ PA68\&lpg=PA68\&dq=dokumenter+fotografi+kuliner Diakses pada tanggal 20 Januari 2019 17:05 